\title{
PENGEMBANGAN MODEL PEMBELAJARAN IMAJINATIF DALAM KETERAMPILAN MENGARANG PADA SISWA SMP DWIGUNA DEPOK
}

\author{
Rahmawati \\ Program Studi Informatika Universitas Indraprasta PGRI \\ Email: rhmarisma10@gmail.com
}

\begin{abstract}
Abstrak
Pembelajaran Bahasa Indonesia di Sekolah Menengah Pertama diarahkan untuk meningkatkan kemampuan peserta didik dalam berkomunikasi dengan bahasa Indonesia yang baik dan benar, baik secara lisan maupun tertulis serta menumbuhkan apresiasi terhadap hasil karya sastra Indonesia. Tujuan penelitian ini adalah untuk mendeskripsikan peningkatan keterampilan mengarang pada peserta didik SMP Dwiguna Depok. Jenis penelitian ini adalah penelitian tindakan kelas, menggunakan model dua siklus tindakan. Subjek penelitian yaitu pada siswa SMP Dwiguna. Data diperoleh melalui instrumen utama, yakni penelitian yang didukung dengan instrumen penunjang berupa observasi, wawancara, dokumentasi, dan catatan lapangan. Hasil penelitian menunjukkan bahwa pada kegiatan mengarang dengan menggunakan model pembelajaran imajinatif telah meningkat, peserta didik kreatif dengan imajinasinya tanpa ada batasan-batasan. Hal itu terlihat dari hasil analisis didapatkan bahwa keterampilan mengarang peserta didik mengalami peningkatan, sehingga model pembelajaran ini dapat digunakan sebagai salah satu alternatif pembelajaran Bahasa Indonesia di kelas.
\end{abstract}

Kata Kunci: Model Pembelajaran, Imajinatif, Keterampilan, Mengarang.

\section{Abstract}

Indonesian Language Learning at Junior High School is performed to improve students' ability to communicate with good and correct Indonesian language, both oral and written, and to foster students' appreciation for Indonesian literary works. The purpose of this study is to describe the improvement of writing skill of students of Dwiguna Depok Junior High School. It is a classroom action research using a two-cycle action model. The subject of the research is Dwiguna junior high school students. Data are obtained from the main instrument, namely research supported by supporting instruments such as observation, interviews, documentation, and field notes. The results show that the writing activity using imaginative learning model has increased, with the students being creative with imagination without any limitations. It is seen from the analysis results showing that the students' writing skill has improved, meaning this learning model can be used as an alternative to Indonesian Language learning in the classroom.

Keywords: Learning Model, Imaginative, Skill, Writing.

\section{PENDAHULUAN}

Keberhasilan proses pembelajaran tidak lepas dari kemampuan guru dalam mengembangkan model pembelajaran yang berorientasi pada peningkatan intensitas keterlibatan siswa secara efektif di dalam proses pembelajaran. Pengembangan model pembelajaran yang tepat pada dasarnya bertujuan untuk menciptakan kondisi belajar secara aktif dan menyenangkan sehingga siswa dapat meraih hasil belajar dan prestasi yang optimal.
Kegiatan belajar mengajar merupakan kegiatan yang paling pokok. Hal ini berarti bahwa berhasil tidaknya pencapaian tujuan pendidikan tergantung pada bagaimana proses belajar mengajar selalu melibatkan dua pelaku aktif, yaitu guru dan peserta didik. Guru sebagai pengajar merupakan pencipta kondisi belajar peserta didik yang didesain secara sengaja, sistematika, dan berkesinambungan, sedangkan peserta didik sebagai subjek pembelajaran merupakan pihak yang menikmati kondisi belajar [1]. 
Bahasa memiliki peran sentral dalam perkembangan intelektual, sosial, dan emosional peserta didik, dan merupakan penunjang keberhasilan dalam mempelajari semua bidang studi. Pembelajaran bahasa diharapkan membantu peserta didik mengenal dirinya, budaya dirinya, budaya orang lain, mengemukakan gagasan dan perasaan, serta berpartisipasi dalam masyarakat yang menggunakan kemampuan analisis dan imajinatif yang ada dalam dirinya.

Pembelajaran bahasa Indonesia diarahkan untuk meningkatkan kemampuan peserta didik untuk berkomunikasi dalam bahasa Indonesia dengan baik dan benar, baik secara lisan maupun tulisan, serta menumbuhkan apresiasi terhadap hasil karya sastra Indonesia [2]. Pembelajaran mengarang sebenarnya sangat penting diberikan kepada peserta didik untuk melatih menggunakan bahasa secara aktif. Di samping itu, pengajaran mengarang secara otomatis mencakup banyak unsur kebahasaan termasuk kosakata dan keterampilan penggunaan bahasa itu sendiri dalam bentuk bahasa tulis. Akan tetapi, ada banyak permasalahan yang dihadapi dalam pembelajaran mengarang. Pembelajaran mengarang juga lebih banyak difokuskan pada pembelajaran teori mengarang, seperti teori penentuan topik, kerangka karangan, out line karangan, memilih judul karangan, penyusunan kalimat, dan penyusunan paragraf.

Berdasarkan observasi peneliti terhadap proses belajar mengajar mata pelajaran Bahasa Indonesia di SMP Dwiguna Depok, terdapat beberapa kendala yang dihadapi dalam proses pembelajaran Bahasa Indonesia, di antaranya: peserta didik mengalami kesulitan dalam memulai tulisan-tulisannya, ide apa yang bisa digali untuk dituliskan, dan bagaimana merangkai ide-ide yang ada menjadi wujud tulisan yang bagus dan dimengerti oleh orang lain. Hal ini terjadi karena proses yang dijalani peserta didik dalam mengarang belum melampaui tahap-tahap yang jelas.

Untuk memenuhi beberapa tahap yang telah disebutkan tersebut, perlu ada koordinasi yang tepat antara ide, keinginan, dan kondisi diri dengan lingkungan. Jika dalam perjalanan mengarang salah satu kondisi tersebut mengalami masalah, maka proses mengarang akan terhambat. Untuk itu, perlu ada suatu pengkondisian lingkungan yang mampu mendukung dan mempertahankan ide serta keinginan peserta didik dalam mengarang.

Berdasarkan hasil wawancara dengan Ibu Isrohayati. M.Pd., beliau menuturkan bahwa pada saat pembelajaran Bahasa Indonesia, beliau sering menggunakan metode ceramah, diskusi, tanya jawab, dan penugasan. Ibu Isrohayati juga menuturkan kendala yang dihadapi peserta didik ketika pelajaran mengarang adalah peserta didik mengalami kesulitan dalam memenuhi tulisan-tulisannya, bagaimana cara merangkai kata-kata yang baik dan banar, serta bagaimana meningkatkan minat peserta didik untuk senang dengan pelajaran mengarang agar lebih menarik dan disukai oleh peserta didik. Dalam hal ini guru harus lebih pintar dalam memilih metode pembelajaran yang sesuai dengan materi pelajaran mengarang. Dengan menggunakan pembelajaran imajinatif, melalui imaji visualnya, peserta didik dapat menciptakan gagasan mereka sendiri. Imajinasi cukup efektif untuk meningkatkan kemampuan peserta didik dalam pembelajaran mengarang karena mereka akan lebih kreatif dalam menuangkan gagasan dalam bentuk tulisan. 
Mengarang merupakan bentuk berpikir yang merupakan alat untuk membuat orang lain membaca. Dengan kegiatan mengarang seorang peserta didik mampu mengkontruksi berbagai ilmu atau pengetahuan yang dimiliki dalam sebuah bentuk karangan, baik dalam bentuk esai, artikel, laporan ilmiah, cerpen, dan puisi, sehingga pembelajaran imajinatif mampu mengatasi permasalahan peserta didik dalam mengarang. Melalui pembelajaran imajinatif ini diharapkan peserta didik mampu berkreasi menuangkan imajinya, berlatih menggunakan bahasa secara aktif dan kreatif, serta meningkatkan minat peserta didik dalam bidang mengarang sehingga tujuan pembelajaran Bahasa Indonesia dapat tercapai.

Berdasarkan permasalah yang ada, maka tujuan penelitian ini adalah mendeskripsikan peningkatan keterampilan mengarang peserta didik pada SMP Dwiguna Depok dengan diterapkannya model pembelajaran imajinatif.

Hasil penelitian ini juga diharapkan dapat memberikan manfaat untuk memaparkan pentingnya menggunakan sebuah model pembelajaran yang tepat dalam pembelajaran, serta bagi sekolah dapat digunakan sebagai bahan pertimbangan dalam rangka perbaikan kegiatan pembelajaran di sekolah.

\section{METODE}

Jenis penelitian yang digunakan pada penelitian ini adalah Penelitian Tindakan Kelas. Penelitian tindakan kelas sangat tepat diterapkan dalam penelitian ini, karena penelitian tindakan kelas dalam proses belajar mengajar dapat meningkatkan mutu praktik pembelajaran.

Penelitian tindakan kelas, guru dapat mencoba gagasan-gagasan yang dapat digunakan untuk memperbaiki proses pembelajaran dan juga dapat melihat secara nyata pengaruh dari upaya tersebut karena penelitian tindakan kelas bersifat reflektif, partisipasif, kolaboratif, dan spiral [3].

Dalam penelitian ini, objek penelitian adalah peserta didik SMP Dwiguna Depok, dilaksanakan pada bulan Maret 2014, lokasi penelitian di Sekolah Menengah Pertama (SMP) Dwiguna Depok, beralamat di Gg. H. Dul No. 30 Kec. Pondok Terong Kota Depok 16442 (Jawa Barat).

Cara yang ditempuh peneliti untuk mendapatkan data-data aktual sesuai dengan fakta yang terjadi saat melakukan penelitian ini, yaitu peneliti menggunakan teknik pengumpulan data sebagai berikut:

a. Tes

Tes merupakan suatu alat atau prosedur yang sistematis dan objektif untuk memperoleh data-data atau keterangan yang diinginkan tentang seseorang dengan cara yang boleh dikatakan tepat dan cepat [4]. Tes diartikan sebagai prosedur yang sistematik untuk mengamati perilaku dan mendeskripsikan satu atau lebih karakteristik seseorang [5]. Tes pada umumnya digunakan untuk menilai atau mengukur hasil belajar siswa berkaitan dengan penguasaan bahan pengajaran.

b. Observasi

Observasi adalah upaya untuk menentukan segala peristiwa dan kegiatan yang terjadi selama tindakan perbaikan itu berlangsung dengan bantuan atau tanpa alat bantuan [6]. Observasi dilakukan untuk mengamati kegiatan di kelas selama kegiatan pembelajaran.

Dalam penelitian ini, observasi merupakan alat bantu yang digunakan peneliti ketika mengumpulkan data melalui pengamatan dan pencatatan 
secara sistematis terhadap fenomena yang diselidiki.

c. Wawancara

Dalam wawancara, peneliti menggunakan wawancara terstruktur, yaitu wawancara yang pewawancaranya menetapkan sendiri masalah dan pertanyan-pertanyaan yang akan diajukan.

Teknik analisis data adalah upaya yang dilakukan dengan data yaitu, mengorganisasikan data, memilahnya menjadi satuan-satuan yang dapat dikelola, mensintesiskannya, mencari dan menemukan pola, menentukan apa yang penting dan dipelajari, serta memutuskan apa yang dapat diceritakan kepada orang lain.

\section{HASIL DAN PEMBAHASAN}

Pada Bab ini, akan dipaparkan hasil penelitian dan pembahasan mengenai penerapan model pembelajaran imajinatif untuk meningkatkan keterampilan mengarang peserta didik pada mata pelajaran Bahasa Indonesia di SMP Dwiguna Depok. Dengan mengacu pada tujuan penelitian, yaitu mendeskripsikan bagaimana peningkatan keterampilan tindakan kelas (PTK). Penelitian memilih PTK karena mempunyai beberapa kelebihan yaitu mudah dilaksanakan oleh guru dan tidak menggangu pembelajaran.

Mengarang sebagai proses kreatif ini telah didukung oleh proses pembelajaran yang didorong dan dimotivasi oleh guru dan peneliti untuk menghasilkan produk yang kreatif. Guru yang bertindak sebagai motivator dan fasilisator benar-benar mengantarkan peserta didik untuk mencapai kompetensi dalam proses pembelajaran berupa kegiatan mengarang sebagai proses kreatif. Pada dasarnya, model pembelajaran imajinatif untuk keterampilan mengarang ini sangat membantu peserta didik untuk membentuk diri menjadi pribadi yang kreatif. Hal itu disebabkan model pembelajaran imajinatif yang membelajarkan peserta didik berkreasi dengan imajinasinya. Mereka bebas menciptakan hal-hal baru, bebas mengembangkan imajinasi, inovasi, dan kreasi dalam menentukan diksi yang menghasilkan pencitraan yang indah dan tepat.

Model pembelajaran imajinatif merupakan suatu model pembelajaran baru bagi peserta didik SMP Dwiguna Kota Depok. Model pembelajaran ini juga mengajak peserta didik agar tertantang untuk mencoba dan bekerja keras dalam mengolah dan menantang ide.

Pada analisis data, penelitian telah menyebutkan bahwa pembelajaran mengarang telah melalui tahap-tahap pembelajaran dan tindakan yang benar. Penyimpulan ini didasarkan pada kesesuaian tahapan awal, pembelajaran dilakukan dengan motivasi, dan memusatkan perhatian peserta didik pada pembelajaran. Selanjutnya adalah tahapan inti, tahapan ini berupa kegiatan mengembangkan pengetahuan, mengembangkan sikap, dan mengembangkan keterampilan. Terakhir adalah tahapan penutup.

Model pembelajaran adalah kerangka konseptual yang melukiskan prosedur yang sistematis dalam mengorganisasikan pengalaman belajar untuk mencapai tujuan tertentu dan berfungsi sebagai pedoman bagi para perancang pembelajaran dan para pengajar dalam melaksanakan aktivitas pembelajaran [7].

Mengacu pada bukti pengamatan yang telah dilakukan dalam penelitian ini, terdapat peningkatan hasil belajar dan keterampilan mengarang pada siswa yang dapat dilihat dalam tabel di bawah ini: 
Tabel 1. Hasil Tugas Mengarang Siswa pada Siklus I

\begin{tabular}{cccc}
\hline No. & Katagori & Frekuensi & Persentase \\
\hline 1. & Benar Semua & 16 & $39,02 \%$ \\
2. & Benar Sebagian & 13 & $31,71 \%$ \\
3. & Salah Semua & 6 & $14,63 \%$ \\
4. & Tanpa & 6 & $14,63 \%$ \\
& Percakapan & & \\
\hline \multicolumn{2}{r}{ Sumber: Data nilai mengarang siswa SMP Dwiguna Depok }
\end{tabular}

Tingkat keberhasilan pada siklus I adalah $39,02 \%+31,71 \%=70,73 \%$. Siswa yang membuat karangan tanpa percakapan sebanyak 6 siswa dan yang membuat karangan dengan percakapan tapi salah cara membuat kutipannya sebanyak 6 siswa.

Hasil tersebut menunjukkan bahwa pada siklus pertama, secara klasikal siswa belum tuntas belajar, karena siswa yang memahami mata pelajaran mengarang hanya sebesar $70,73 \%$ lebih kecil dari presentase ketuntasan yang dikehendaki yaitu sebesar $85 \%$.

Tabel 2. Hasil Tugas Mengarang Siswa pada Siklus II

\begin{tabular}{lllc}
\hline No. & Katagori & Fre & Persentase \\
\hline 1. & Benar Semua & 18 & $43,92 \%$ \\
2. & Benar Sebagian & 15 & $36,58 \%$ \\
3. & Salah Semua & 4 & $9,75 \%$ \\
4. & Tanpa Percakapan & 4 & $9,74 \%$ \\
\hline \multicolumn{4}{c}{ Sumber: Data nilai mengarang siswa SMP Dwiguna Depok }
\end{tabular}

Tingkat keberhasilan pada siklus II adalah $43,93 \%+36,58 \%=80,50 \%$. Siswa yang membuat karangan tanpa percakapan sebanyak 4 siswa dan yang membuat karangan dengan percakapan tapi salah cara membuat kutipannya sebanyak 4 siswa. Hasil ini menunjukkan bahwa ketuntasan belajar mencapai $80,50 \%$.

Hasil tersebut menunjukkan bahwa pada siklus II ini ketuntasan belajar secara klasikal telah mengalami peningkatan sedikit lebih baik dari siklus I.
Tabel 3. Hasil Tugas Mengarang Siswa pada Siklus III

\begin{tabular}{|c|c|c|c|}
\hline No. & Katagori & Frekuensi & Persentase \\
\hline 1. & Benar Semua & 21 & $51,22 \%$ \\
\hline 2. & Benar Sebagian & 16 & $39,02 \%$ \\
\hline 3. & Salah Semua & 4 & $9,76 \%$ \\
\hline 4. & $\begin{array}{l}\text { Tanpa } \\
\text { Percakapan }\end{array}$ & - & - \\
\hline
\end{tabular}

Tingkat keberhasilan pada siklus III adalah $51,22 \%+39,02 \%=90,24 \%$. Siswa yang membuat karangan tanpa percakapan tidak ada dan yang membuat karangan dengan percakapan tapi salah cara membuat kutipannya sebanyak 4 orang. Hasil ini menunjukkan bahwa ketuntasan belajar mengajar 90,24\% atau ada 37 siswa yang tuntas belajar.

Hasil ini menunjukkan bahwa siklus III menujukkan ketuntasan belajar secara klasikal telah tercapai. Adanya peningkatan hasil belajar pada siklus III ini dipengaruhi oleh adanya peningkatan kemampuan guru dalam menerapkan model pembelajaran imajinatif dalam keterampilan mengarang sehingga siswa menjadi lebih terbiasa dengan pembelajaran seperti ini.

\section{SIMPULAN}

Berdasarkan hasil penelitian tindakan yang dilakukan, penelitian ini memperoleh kesimpulan sebagai berikut:

1. Pengembangan model pembelajaran imajinatif memiliki dampak positif dalam meningkatkan prestasi belajar siswa dalam mengarang. Hal ini dapat dilihat dari semakin mantapnya pemahaman siswa terhadap materi yang disampaikan guru dengan ketuntasan belajar meningkat dari siklus I yaitu70,73\%, siklus II yaitu $80,50 \%$, dan Siklus III yaitu 90,24\% pada siklus ini ketuntasan belajar siswa klasikal telah tercapai.

2. Kemampuan guru dalam mengelola pembelajaran mengalami peningkatan. 
Hal ini berdampak positif terhadap prestasi belajar siswa yaitu dapat ditujukkan dengan meningkatnya nilai rata-rata siswa pada setiap siklus yang terus mengalami peningkatan.

\section{DAFTAR PUSTAKA}

[1] M. Fathurrohman. Belajar dan Pembelajaran Membantu Meningkatkan Mutu Pembelajaran. Yogyakarta: Teras, 2012.

[2] P. Wiedarti. Мепији Budaya Menulis: Suatu Bunga Rampai. Yogyakarta: Tiara Wacana, 2005.

[3] M. Muslich. Melaksanakan PTK itu Mudah (Classroom Action Research) Pedoman Praktis Bagi Guru Propesional. Jakarta: Bumi Aksara, 2011.

[4] Sulistyorini. Evaluasi Pendidikan dalam Meningkatkan Mutu Pendidikan. Yogyakarta: Tras, 2009.

[5] R. Indriastuti. Penyajian Data Statistik. Yogyakarta: PT. Citra Aji Pratama, 2012.

[6] Siswono. Mengajar dan menulis. Surabaya: Unesa University, 2008.

[7] U. Winataputra. Model-Model Pembelajaran Inovatif. Jakarta Pusat: Direktorat Jenderal Pendidikan Tinggi Departemen Pendidikan Nasiona 